\title{
CORPORAL PUNISHMENT IN MALAYSIAN PUBLIC SCHOOLS: LEGAL AND EDUCATIONAL PERSPECTIVES
}

\author{
Usharani Balasingam* \\ Azmawaty Mohamad Nor** \\ Shanina Sharatol Ahmad Shah***
}

\begin{abstract}
There is a need to consider whether the current school environment cum climate and punishment for indiscipline or behaviour management in Malaysia is relevant and effective in the current age. Foundational values primarily begins at home and in schools. In this regard the school is viewed not only as a place of learning but as a community of relationships where bonds are built where characters and values are shaped. It needs to be a conducive environment for the successful realisation of the Malaysian Education Blueprint (2013-2025) to develop value driven, tolerant and responsible Malaysians. It is a place to nurture inclusivity, respect for the person, consideration, cooperation, respect for diversity, unity, trust and other values desired under the Education Ministry. In this regard, this paper argues that Malaysia Education (School Discipline) Regulations 1959 which was made under a repealed Act need to be reconsidered for its effectiveness. The impact of corporal punishment and violence on children is covered in this paper in addition to relevant court decisions involving teachers and schools. Malaysia has acceded to the Convention for the Rights of the Children, this paper explores the compatibility of the convention with the School discipline Regulation 1959.
\end{abstract}

Keywords: Corporal Punishment, School Discipline, Convention on the Rights of the Child, Education (School Discipline) Regulations 1959, positive discipline, whole school and restorative practice

\footnotetext{
* Corresponding author, Senior Lecturer at the Faculty of Law, University of Malaya. Email: usha@um.edu.my or usharanibalasingam@gmail.com.

** Senior Lecturer at the Faculty of Education, University of Malaya. Email: azy_mn@um.edu.my.

*** Senior Lecturer at the Faculty of Education, University of Malaya. Email: shanina@um.edu.my.
} 


\title{
HUKUMAN KORPORAL DI SEKOLAH AWAM DI MALAYSIA: SUDUT PANDANGAN PERUNDANGAN DAN PENDIDIKAN
}

\begin{abstract}
ABSTRAK
Adalah perlu untuk dipertimbangkan samada persekitaran atau iklim sekolah semasa dan hukuman korporal untuk kes disiplin kini adalah relevan dan berkesan dalam keadaan semasa. Nilai-nilai asas adalah disemaikan semasa muda di rumah dan di sekolah. Sekolah bukan sahaja tempat untuk menimba ilmu tetapi satu komuniti perhubungan persaudaraan di mana pertalian dibina, perwatakan dicorakkan dan nilainilai disemai. Adalah perlu untuk satu persekitaran yang konduksif untuk merealisasikan membentuk insan bersemai nilai, bertoleransi dan bertanggungjawab dibawah Pelan Cetakbiru Pendidikan Malaysia (20132025). Persekitarannya adalah untuk menghidupkan nilai penerimaan, penghormatan untuk individu, pertimbangan, koperasi, menghormati perbezaan, kesatupaduan, kepercayaan serta nilai lain yang diidamkan oleh Kementerian Pendidikan. Dalam pekara ini, kertas ini memberi pandangan bahawa Regulasi Pendidikan (Disiplin Sekolah) 1959 Regulasi yang dibuat di bawah Ordinan Pendidikan 1957 yang sudah di mansuhkan perlu dikaji semula samada ianya efektif untuk menangani pentadbiran kelakuan dalam dunia masa kini yang berlaku juga di alam maya. Kaedah alternatif perlu juga di pertimbangkan khususnya dalam isu kanak-kanak yang belum dewasa. Lebih-lebih lagi bila ada kajian yang melaporkan kesan negatif hukuman korporal dan keganasan atas kanak-kanak yang di kaji dalam kertas ini. Malaysia telah mengesahkan Konvesyen Hak KanakKanak, kajian atas keseiringannya dengan regulasi 1959 menjadi asas kajian kertas ini.
\end{abstract}

Kata Kunci: Hukuman Korporal, Disiplin Sekolah, Konvesyen Hak Kanak Kanak, Regulasi Pendidikan (Disiplin Sekolah) 1959, disiplin positif, sekolah lengkap dan praktis restoratif.

\section{INTRODUCTION}


It is reported that almost 47 per cent of parents surveyed think physical punishment should be allowed in schools while 20 per cent disagree. Similarly, more than 80 per cent use physical punishment at home and are more likely to support the its use. ${ }^{1}$ This is distinct from flights of rage or anger where teachers inflict physical punishment. ${ }^{2}$ This may be viewed as discipline or behaviour management issue from the sides of teachers, students and even among students. It reflects the school climate and environment including how anger or misbehaviour is being dealt with in Malaysian schools. Some examples covering the same misconduct by student and teachers alike are reflected in Table 1 herein.

Table 1. Teachers in the news (2017)

\begin{tabular}{|l|l|}
\hline Month & Incident \\
\hline Dec & $\begin{array}{l}\text { Azizan (a teacher) 44 was accused of slapping a male pupil } \\
\text { aged 11 for being involved in glue-sniffing, bullying and } \\
\text { playing truant. }\end{array}$ \\
\hline Nov & $\begin{array}{l}\text { A girl, 8, suffered bruises after she was beaten with a ruler } \\
\text { and pinched at a Chinese school in Kuala Lumpur. Her } \\
\text { teacher was unhappy with her IT project. }\end{array}$ \\
\hline Sept & $\begin{array}{l}\text { A police report was lodged after a girl aged 4, suffered } \\
\text { injuries to her ears and back in Johor Bahru. Her } \\
\text { kindergarten teacher struck her for not writing neatly. }\end{array}$ \\
\hline Aug & $\begin{array}{l}\text { A religious teacher aged 31, was charged with pulling the } \\
\text { nose of his 12-year-old student in Wangsa Maju. The father } \\
\text { of three who had been teaching for more than a decade was } \\
\text { injured after being attacked by the student's father. }\end{array}$ \\
\hline Aug & $\begin{array}{l}\text { A private school and its teacher were sued for failing to } \\
\text { prevent a seven-year-old boy from being bullied by his }\end{array}$ \\
\hline
\end{tabular}

\footnotetext{
${ }^{1}$ Kim Ho, "Malaysian Parent Spilt on Corporal Punishment." Yougovomnibus, July 8, 2019, https://my.yougov.com/en-my/news/2019/07/08/malaysianparents-split-corporal-punishment-school/

${ }^{2}$ Coordinator "When Malaysian School Authorities use the rod and physically harm the child" April 28, 2017, National Human Rights Society, https://hakam.org.my/wp/2017/04/28/when-malaysian-school-authorities-usethe-rod-and-physically-harm-children/\#more-13991.
} 


\begin{tabular}{|c|c|}
\hline & classmates in Kuala Lumpur. \\
\hline Aug & $\begin{array}{l}\text { A secondary school teacher in Johor Bahru hit a student } \\
\text { aged 13, with a broom breaking three of her fingers. }\end{array}$ \\
\hline July & $\begin{array}{l}\text { A } 32 \text {-year-old mother lodged a police report after her } 3 \text { - } \\
\text { year- old son was hit on the head by his teacher when he } \\
\text { could not answer questions. }\end{array}$ \\
\hline July & $\begin{array}{l}\text { A police report was lodged against a Port Dickson primary } \\
\text { school teacher for placing a heated metal sharpener on his } \\
\text { pupil's cheek. The boy was playing in his classroom during } \\
\text { lessons. }\end{array}$ \\
\hline July & $\begin{array}{l}\text { A teacher who hit, slapped and kicked a pupil aged } 11 \text { was } \\
\text { transferred and counselled. The boy was hit with a plastic } \\
\text { table cover for throwing a classmate's shoe from the third } \\
\text { floor of the school. }\end{array}$ \\
\hline June & $\begin{array}{l}\text { A discipline teacher in Kapar was transferred after hitting a } \\
\text { Form Two student with a shoe. }\end{array}$ \\
\hline June & $\begin{array}{l}\text { A vocational college student in Kota Kinabalu sustained a } \\
\text { deep bruise on her thigh after being beaten with a broom } \\
\text { handle by her teacher. }\end{array}$ \\
\hline April & $\begin{array}{l}\text { A teacher in a private religious boarding school was charged } \\
\text { in court after the boy's parents found him weak and covered } \\
\text { in bruises. He was admitted for } 2 \text { weeks in Klang hospital. }\end{array}$ \\
\hline April & $\begin{array}{l}\text { A boy, } 11 \text { suffered severe infection on his limbs. He was } \\
\text { beaten by the assistant warden with a rubber hose for } \\
\text { making noise at a private religious school in Johor Bahru. }\end{array}$ \\
\hline April & $\begin{array}{l}\text { An } 8 \text {-year-old boy in Kota Kinabalu was hit in the head by a } \\
\text { wooden chair thrown by the teacher intended for another } \\
\text { student who was causing nuisance in class. }\end{array}$ \\
\hline March & $\begin{array}{l}\text { A math teacher was charged in a magistrate court in } \\
\text { Petaling Jaya for pinching a 9-year-old student's ear. }\end{array}$ \\
\hline March & $\begin{array}{l}\text { A mother was fined and jailed for slapping a teacher in } \\
\text { Sungai Bakap. The mother claimed her } 8 \text {-year-old son's } \\
\text { nape of the neck was pinched. }\end{array}$ \\
\hline
\end{tabular}




\begin{tabular}{|l|l|}
\hline March & $\begin{array}{l}\text { A tuition teacher in Johor Bahru scalded her 7-year-old } \\
\text { pupil's buttocks with heated wok to remove marks that were } \\
\text { left after she caned him. }\end{array}$ \\
\hline Jan & $\begin{array}{l}\text { A student in Kulai was beaten with a shoe by a disciplinary } \\
\text { teacher for talking in class. }\end{array}$ \\
\hline Jan & $\begin{array}{l}\text { The father of a secondary school student lodged a police } \\
\text { report after he was punched by a teacher over a } \\
\text { misunderstanding about the school session registration. }\end{array}$ \\
\hline
\end{tabular}

(Source: The Star, Stareducate January 72018 ) $^{3}$

This is aside from the tragic and sad case of the death by abuse of student Mohd Thaqif Amin Mohd Gaddafi in the name of discipline. ${ }^{4}$ It is evident that teachers too need to be trained and informed on positive methods to address indiscipline by students and to control and manage their reactions especially in primary school classrooms.

These cases raise the question as to how effective is the law in Malaysia on indiscipline in schools. The earliest regulations relating to this issue could be found in legislation that was enacted in 1959 under the repealed Education Ordinance 1957 which will be explored in the article. Malaysia has since ratified the Convention on the Rights of the Child $^{5}$ (CRC) and passed two revised Education Acts. ${ }^{6}$ This then leads to the question, as to whether there have been improvements made to the management of indiscipline in Malaysian public schools. Are there

3 "The STAR, January 7, 2018., p. 7. Reference can also be made to April 28, 2017Coordinator When Malaysian School Authorities use the rod and physically harm the child https://hakam.org.my/wp/2017/04/28/when-malaysianschool-authorities-use-the-rod-and-physically-harm-children/\#more-13991

${ }^{4}$ United Nations Children's Fund. Corporal punishment kills, positive discipline teaches. (2017b) Accessed July $26 \quad 2018$ https://www.unicef.org/malaysia/corporal_punishment_discipline teaches.html\# .W40YUOgzY2W

${ }^{5}$ United Nation Convention on the Rights of the Child. Malaysia acceded with reservation on the 17 February 1995. Accessed September 28, 2018. https://treaties.un.org/Pages/ViewDetails.aspx?src=TREATY\&mtdsg_no=IV$11 \&$ chapter $=4 \&$ clang $=$ en

${ }^{6}$ Federation of Malaya Education Act 1961 (Act 43) which was repealed by Section 155 Education Act 1996.(Act 550). 
alternatives that would foster a better school climate? Is Malaysia in compliance with her legal obligations under $\mathrm{CRC}$, the current regulations and mode of discipline? These pertinent issues are addressed in this article. In order to decide the future pathway of management of behaviour and indiscipline in the country, reported studies on violence on children are also covered for consideration.

\section{METHOD AND STRUCTURE OF THE STUDY}

This article is based on a doctrinal study and review on the regulations relating to the administration of discipline in local public school. The primary question that is addressed in this work is whether Malaysia's regulations, which were enacted in 1959, conforms to the Malaysian international obligations owed under the Convention on the Rights of the Child (CRC).

The work primarily reviews the United Nations reports and findings on the impact of violence at school for further consideration by the relevant authorities on how to handle discipline or manage misbehaviour in schools. This raises the issue of the need to further explore positive discipline and restorative practices in schools under the "whole school" concept. This concept in itself requires further research and is not the subject-matter of this study except for incidental references. The discussion in the next part of this article analyses the Malaysian regulatory framework.

\section{THE MALAYSIAN REGULATORY FRAMEWORK}

The Education Regulation (School Discipline) $1959^{7}$ and Ministry of Education Circular 2003 on Corporal Punishment, ${ }^{8}$ the school Principal is given the authority over school discipline. Specifically, Regulation 4 which reads:

"The head teacher of a school shall be responsible for the discipline of the school and for such purpose shall have authority over the other teachers and pupils of the school."

\footnotetext{
${ }^{7}$ Education (School Discipline) Regulations 1959 L.N. 61.

8 Ministry of Education Circular No $7 / 2003$ Power to Cane KP(BS) 8591/Jld.XVIII (7) 29 Oktober 2003.
} 
Regulation 5 reads:

(1) For the purposes of maintaining discipline among pupils the head teacher shall power to inflict such ordinary school punishment as may be necessary or expedient: Provided that

(a) Corporal punishment of girl pupils is prohibited; and

(b) Corporal punishment of boys by a teacher or other member of the staff shall be limited to blows with a light cane on the palm of the hand or on the buttocks over the clothes and shall be inflicted only by the head teacher or by his express authority given in the specific case.

(2) A record of all punishments inflicted under paragraph (1) shall be kept confidentially in a form approved by the Registrar.

Regulation 6 deals with the power of the Head teacher to delegate the disciplinary authority by express directions to other registered teachers in the school or to such pupils as he may appoint for such a purpose.

Regulation 8 deals with the power of the Head teacher to suspend or expel students which is wide and discretionary in the hands of the Headmaster. Regulation 8 reads:

Whenever it appears to the satisfaction of the head teacher of any school -

(a) To be necessary or desirable for the purpose of maintaining discipline or order in any school that any pupil should be suspended or expelled...he may by order expel him from such school.

The Anandarajan v Mahadevan, ${ }^{9}$ case is in relation to the action of the Headmaster who expelled a student. The headmaster case was that the student was expelled due to his misbehaviour at a talent time held in the school on $1^{\text {st }}$ April, 1968 wherein reports were made against him by the teacher in charge of the show, the head prefect and chairman of the Interact Club. He called the student and some other boys on the $2^{\text {nd }}$ April, 1968 to inquire into the reports. He questioned them together and later interviewed them one by one. At the interview, he asked the student of his alleged misbehaviour at the talent time and on previous occasions.

${ }^{9}$ Anadarajan v Mahadevan (1971) 2 Malayan Law Journal p 8-11. 
The student admitted to some and denied the others. He decided after the interview to expel the student but wanted to consult his colleagues and made up his mind on the $10^{\text {th }}$ April, 1968.

However, since the school was about to close for break and as he had official business to attend in Johor Baharu, he conveyed his decision to the student on $6^{\text {th }}$ May, 1968 when the school reopened. The student's version was that the Headmaster made an announcement in the school hall that a student was to be expelled on $6^{\text {th }}$ May, 1968 and he was called into the headmaster office and was informed he was expelled and told to go home. A school leaving certificate was subsequently sent to his father and the student's appeal to the Board of Governors failed. The court action in the High Court was in favour of his reinstatement, which was appealed by the Headmaster and the other two respondents. The student also said that on $10^{\text {th }}$ April, 1968 he was called and harassed by the Headmaster and he made a police report on the same day.

The argument of the student was that having satisfied himself on the truth or falsity of the allegations, the Headmaster should have allowed the student an opportunity to show cause as to why he should not be expelled. This argument was rejected by the court holding that the headmaster "cannot be expected to hold an elaborate inquiry before making an order".

The Headmaster allege that the student answered some of the charges and denied the rest on the $2^{\text {nd }}$ April 1968.The misconduct alleged was that he sat in a three dollar seat having paid for a two dollar seat and left the hall a few times to cause interruption. As to his attitude to prefects he remained quiet. He gave a medical certificate to be absent from afternoon games but was found to be playing other games. $\mathrm{He}$ admitted running away from school activities but explained that it did not hurt him if he played badminton. The allegation he denied was that he shouted filthy words and flicked matches.

Based on the above the court found as evidence that he was given the opportunity to state his case. The court did not require any formality or procedure to enable the Head master to reach his decision. It has been decided in the case of Anandarajan v Mahadevan on this aspect that the decision of the Headmaster is subject to judicial review. However, it was also decided in the case that the audi alteram partem principle was to be applied upon most general considerations to uphold the expulsion. 
The case is a reflection of seemingly absolute power and authority of Headmaster. Would it stand the test of time today? Should the student be given an opportunity to shew cause why the student should not be expelled given the devastating consequences?

The relevant school authorities need to decide: i) the best tool to shape school children, ii) to what extent should this be subjective and if there are no better alternatives to the current mode and forms. It must be noted that juvenile justice and court systems are towards rehabilitation and alternative modes of punishment like community service rather than mere punitive measures.

It is also to be noted that the disciplinary regulation of 1959 still exists and remains under a repealed, pre-Malaysia Education Ordinance 1957 which was repealed and substituted by the Education Act 1961 and thereafter by the Education Act 1996. ${ }^{10}$ Malaysia has moved ahead in her education philosophy, vision and mission. It is timely to review the approach to school discipline not just from occurrence, management ${ }^{11}$ and infliction of punishment as deterrent but from school climate or environment lens. There must be shifts that would emphasize the creation of an environment that pre-empts the social ills through students- teacher interaction towards reducing misbehaviour and if required shape behaviour by positive discipline rather than focus on the effect of misbehaviour and punishment.

The principal is authorised to expel, suspend or impose other punishment that includes corporal punishment, detention, fine and issue warning against students. The administration of corporal punishment is permitted by the circular only on male students in private. Here in this Malaysian context, corporal punishment means physical punishment.

It is to be recognised that restorative practices are not the normal response to discipline issues that are govern that under the Education (School Discipline) Regulations 1959 and the 2003 Circular on Corporal

\footnotetext{
${ }^{10}$ Federation of Malaya No 2 of 1957. The Education Ordinance 1957 was repealed by Federation of Malaya Education Act 1961 (Act 43).The latter was repealed by Section 155 Education Act 1996.(Act 550)

${ }^{11}$ Ministry of Education Circular No 7 /2011 ( SPI :KP BPSH-SPDK) 2011 /005/01/JLD 4 (10) 28 Jun 2011.) Standard Operating Procedure 1:3: 7 Reporting and Handling of Students Discipline.
} 
Punishment which features the retributive responses that are exclusionary and punitive. It is to be noted that the Ministry Circular No 7 of 2003 para 3 states that the infliction of private canning must be done as a process of discipline and not to inflict physical or mental pain on the student.

It is suggested that this should be a more viable argument by proponents of physical punishment that this is not cruel, torture or other degrading treatment of a child rather than argue for entering a reservation under Art 37 of the CRC to permit inflicting such a punishment. The consequence of such a reservation is that it is too wide and open up the child to other situation outside the school environment. This is aside from the fact that such punishment undermines the sanctity of the basic rights sought to be safeguarded under the Convention.

In the absence of authority given by the Head, or if the physical punishment is excessive or in other forms, then the infliction of physical punishment could amount to an assault and battery accusation against the teacher. The case of Mohammed Ariff $v$ Public Prosecutor ${ }^{12}$ is a case of a sexual assault by a religious education teacher in the school classroom. The accused was convicted under Section 354 of the Penal code on two counts of using criminal force with intent to outrage the modesty of an eight year old child. As the Judge pointed out, "Parents are entitled to expect that their children will be in safe hands when they are in school." It is a criminal action, but it does not negate possibilities of civil action against the teacher and/or school.

It opens up the possibility of not only the teacher being sued but the school authorities under the concept of vicarious liability in the appropriate circumstances. ${ }^{13}$ The case of Nurul Atikah is regarding a claim for personal injuries suffered by the student while taking part in a physical education class when a portable basketball hoop/post broke and hit her back. Her claim was against the physical teacher, principal and the third defendant i.e., the school and employer of the first and second defendants. As stated by the Judge Vazeer Alam J at para 32,

\footnotetext{
${ }^{12}$ Mohammed Ariff v Public Prosecutor [2010] MLJU 1976 where the teacher was convicted of sexual assault .

${ }^{13}$ Nurul Atikah binti Mustafa ( suing by parents Mustafa Kamal bin Omar) $v$ Nurazlina Suraini [2019] MLJU 178 .
} 
"The $3^{\text {rd }}$ Defendant as the statutory body vested with responsibility to manage and administer the MRSM, including, but not limited to the employment of teachers and selection of students and setting the rules and regulations governing the operations of the MRSM, would be vicariously liable for the breach of any duty of care owed by the teacher to the student."

The possibility of legal action whether against the teacher or student or school should be another factor. Hence the need to consider an approach that not only prevents unwanted legal consequences. ${ }^{14}$

It has been argued that "ordinary" corporal punishment is strongly linked to a risk of abuse. ${ }^{15}$ It is also argued that those who receive corporal punishment are also likely to perpetuate it. ${ }^{16}$ Also, even if there are other options available under restorative justice and mode of managing misbehaviour could be explored through the right ethos, training and support available to teachers.

The Ministry of Education 2003 circular prescribes the offences that can be subject to corporal punishment. ${ }^{17}$ Corporal punishment is only for schoolboys and is limited to blows with a light cane on the palm of the hand or on the buttocks over his clothes and can be done only by the principal or any authorised staff. This circular continues to recognize the

\footnotetext{
${ }^{14}$ New Jo Lyn "Why are so many Malaysian parents slapping/suing/ scolding school teachers nowadays" Cilisos.my 4 January 2018 https://cilisos.my/whyare-so-many-malaysian-parents-slappingsuingscolding-school-teachersnowadays/

15 Global Initiative to end all Corporal Punishment of Children Corporal Punishment of Children: a Review of research on its impact and Associations 2016 http://endcorporalpunishment.org/wp-content/uploads/research/Researcheffects-review-2016-06.pdf, p 4, accessed 1 Nov 2019.

${ }_{16}$ Global Initiative to end all Corporal Punishment of Children Corporal Punishment of Children : a Review of research on its impact and Associations 2016 http://endcorporalpunishment.org/wp-content/uploads/research/Researcheffects-review-2016-06.pdf , accessed 1 Nov 2019.

17 Ministry of Education Circular No $7 / 2003$ Power to Cane KP(BS) 8591/Jld.XVIII (7) 29 Oktober 2003. See also. Rajaendram, R. "Caning allowed under guidelines". The STAR ,May 12 2016, https://www.thestar.com.my/news/nation/2016/05/12/caning-allowed-underguidelines-school-heads-can-punish-students-for-serious-offences-says-dg/, accessed July 232018.
} 
offences as "heavy", "medium" and "light". There a list of offence under each category that may be added to at the discretion of the principal. Corporal punishment in Malaysian schools is known to be a form of disciplinary action to manage misbehaviour by students. Minor transgressions such as incompletion of homework for 3 times have also been known to receive physical punishment. ${ }^{18}$

For more heavy and serious offences there are 35 items listed that may be added to. Examples would be like threatening educators or other students, drug related issues and peeping (insulting the modesty of others). Others are bullying, distributing pornography materials, rudeness towards a teacher, prefect or student, bringing a guest from outside school without permission and starting a fight, students (offenders) are given up to up to three strokes of a light cane on their buttocks. It is to be admitted however rudeness to teacher or prefect or utterance of threats may be a subjective matter. It is meant to assert and preserve power and dominance. Relevancy and currency of the list is also a matter for consideration.

For offenders who commit medium or moderate labelled offences, there are 10 listed and subject to additions. Behaviours under this category includes: vandalisation of school facilities, cheating during examinations or leaving school without permission for which students (offenders) can be caned up to three times on the palms. In the event that the medium offence is repeated the fourth time it then becomes a serious offence. Warnings will be given to students for misdemeanours such as playing in the classroom, failing to bring specific books to class, failing to be present in class, keeping beards or goatees. These students will then need to attend counselling with school counsellors. ${ }^{19}$

It is noted that the current problems in school like bullying, cyberbulling and drugs are problems that cannot be expelled, suspended or caned away. ${ }^{20}$ The guidelines for the prevention and dealing with

18 Ministry of Education Circular No $7 / 2003$ Power to Cane KP(BS) 8591/Jld.XVIII (7) 29 Oktober 2003.

${ }^{19}$ Ministry of Education Circular No $7 / 2003$ Power to Cane KP(BS) 8591/Jld.XVIII (7) 29 Oktober 2003.

${ }^{20}$ Mohd, H, Revealed: "Full list of 402 Malaysian schools with disciplinary, drug issues." New Straits Times August $17 \quad 2017$ 
bullying among students in schools involves only the school principal, discipline teacher, counsellor and wardens in residential schools and the offender. ${ }^{21}$ The punishments include stern warning (with parents as guarantors), restricted use of facilities, participation in activities, caning, suspension (14 days) or expulsion (where there is serious injury or loss of life).

In case of restorative practices especially interactions and treatments (change in behaviour patterns) that are required to be addressed specifically and target the underlying issues of conflict that bring up such behaviour, more so in cases of bullying. There should be an obligation to provide reformation and integration back in the school community. This is in line with a caring society and to avoid the school-to-adult criminal delinquency that is fostered when the same is not redressed in school by exercising expulsion or suspension option.

It has been reported that Malaysia is not ready to ban caning or corporal punishment. According to National Union of the Teaching Profession president, Kamarozaman Abd Razak this is due to shortage of counsellors which stands at, "... the ratio of students to counsellors in Malaysia stands at 500:1". In other words, it is difficult for counsellors to focus on a single student for as long as it takes to elicit the desired change in attitude. On the other hand, Parent Action Group for Education Malaysia (Page) chairman, Datin Noor Azimah Abdul Rahim, said Page supports UNICEF's call. "Even if it is merely to scare a child, caning is considered inhumane. It is a form of psychological bullying," 22

However, it is demonstrated the idea may be misconceived and that one counsellor per student may not be necessary as envisaged. The idea of a whole school involvement as a philosophy anticipates the involvement of the school in creating a safe healthy and violence free environment.

https://www.nst.com.my/news/nation/2017/08/268913/revealed-full-list-402malaysian-schools-disciplinary-drug-issues, accessed July 282018.

${ }^{21}$ Malaysia Ministry of Education Circular 8 of 2010. Guidelines to prevent and deal with bullying among students in schools.

${ }^{22}$ Perimbanayagam, K. "Is Malaysia ready to ban corporal punishment in schools? Experts weigh in". New Straits Times April 282017 https://www.nst.com.my/news/nation/2017/04/234649/malaysia-ready-bancorporal-punishment-schools-experts-weigh, accessed July 242018. 
Hence there is a need to take measures to make the school environment healthy, safe and a refuge by tackling the roots of indiscipline behaviours. The first point of contact is the classroom hence the positive discipline techniques should be imparted to teachers. A recent study suggests that positive discipline programmes that starts in the classroom is bearing positive feedback where the focus is teaching the student better behaviour than punishing them. ${ }^{23}$ Additionally, the highquality teaching by teachers is the factor that transforms students' behaviour in the classroom - for the better. ${ }^{24}$

In any event notwithstanding the existence of corporal punishment, there is a need for educators to buy into the concept of positive discipline. They stand as role models and participants in shaping their students discipline from the classroom. Teachers' training and professional development is crucial to producing world class education. This needs a serious review to weed out incompetent teachers. It is mooted that there should be a targeted voluntary separation scheme to phase out teachers who have no passion for teaching as they are damaging to the students who rely on them for inspiration, direction and hope. ${ }^{25}$

Child therapist Priscilla Ho is reported to have said:

“...connection is the most effective in ensuring discipline. Don't stigmatise or shame the child ...Caning is ineffective as children will just get used to it. Pinching, slapping and pulling ears are not only detrimental but abusive. It's a crime. To put another person down -what more a child is a sign of weakness, not strength."

She suggested that training of teachers should involve more in-depth learning of child development and psychosocial development. ${ }^{26}$

${ }^{23}$ United Nations Children's Fund. A familiar face: Violence in the lives of children and adolescents. (2017a), https://www.unicef.org/publications/files/Violence in the lives_of_children an d_adolescents.pdf, accessed July 242018.

${ }^{24}$ Hussin, Z. H., Jusoff, K., \& Omar, M. W.. Perception of students teaching quality determinants and effectiveness. Asian Social Science, 4(12), ( 2008) 113-117.

${ }^{25}$ Mustafa, Z. "Wish list for the Education Minister.” New Straits Times, June 27 2018 Accessed $\quad$ July $\quad 27 \quad 2018$ https://www.nst.com.my/education/2018/06/384582/wish-list-education-minister ${ }^{26}$ Chin, C. "Listen not push". The Star, January 7 , 2018 p. 7. 
Positive discipline is when non-physical punishment towards misbehaviour by school children. This is due to the recognition that behaviour can be managed with alternative measures that do not have negative implications and is not due to power dominance. But positive discipline could be difficult if there is a need to adhere to the circulars and guidelines that supports physical punishment element. Obviously, this should be covered in teacher training modules and practised in a school that has embraced the ethos, structure, processes and skills in place. There should be a school leadership that drives and embeds the culture within the school.

The National Union of the Teaching Profession (NUTP) secretary General Harry Tan is reported to have said that the 1983 circular should be reviewed. He said:

"Now only caning for boys is allowed but if he was merely talking in class, is it fair to use the rod? If not, what else can the teacher do? We need new more specific guidelines on permitted punishment methods which are compatible with the challenges faced by the teachers" 27 .

Restorative practices and positive discipline principles are suggested. In such cases, any response should be connected to the misbehaviour, proportionate, focuses on behaviour correction, not humiliation and is rehabilitative. But the foremost action is to decide if discipline is appropriate by evaluating the reasons for misbehaviour and deciding if discipline is the appropriate response.

The next part of the article continues with an analysis of a hypothetical situation where the negative impact of using physical punishment is illustrated.

\section{Positive Discipline: Illustrated ${ }^{28}$}

Aisa, a secondary student, and she is late to school. Aisa lives in a children's home and walks $3 \mathrm{~km}$ to school as she has no money to take the

\footnotetext{
27 "No to abuse yes to discipline." The STAR,January 7, 2018., p. 7.

${ }^{28}$ Naker, D., \& Sekitoleko, D. Positive discipline: Creating a good school without corporal punishment. (2009), https://resourcecentre.savethechildren.net/node/6228/pdf/6228.pdf, Accessed July 282018 .
} 
bus. She has her chores in helping to make breakfast and clearing up to do in the morning. She is tired and arrives late knowing she will be beaten. She submits to being beaten. The teacher believes that she has to make students understand that coming late to school is not acceptable and they know the consequences. Some just offer themselves up to be beaten because they know the teacher will not listen to any excuse.

In this case the teacher could begin by trying to understand the reason for lateness as some maybe beyond the student control. The beating just teaches Aisa she will experience pain. She will get used to it and never learn from it and it might make her resentful and vindictive. The teacher can hold a discussion in class about the importance of being on time and the values behind punctuality which the class can make a list of. Sabrina could be offered counselling and this may involve her writing a letter to explain or to apologise to class for arriving late. It also may involve getting in touch with the caregiver to explain why she must arrive to school on time and how this may be accommodated. Perhaps, even finding a classmate or volunteer that could give her a lift or sourcing a bicycle could help. But if the cause is related to her disrespect to punctuality by persistent lateness then she has to understand that her actions have consequences and she may be not allowed to join the first class. She would need to catch up on her own. She will learn she has the power to change her situation by coming on time. But this would be a last resort option.

With this scenario in mind, the article continues to look at the definition of violence and its impact on children, particularly in schools is discussed in the next part.

\section{DEFINITION OF VIOLENCE AND IMPACT ON CHILDREN.}

The CRC, under article 19, mandates States Parties to take all appropriate measures, including, enacting legislation, to protect children from all forms of violence while in the care of parents, guardians or other caregivers. ${ }^{29}$ In General Comment No. 8, the Committee on the Rights of

${ }^{29}$ United Nations General Assembly, Convention on the Rights of the Child, A/RES/44/25, United Nations, New York, 20 November 1989, available at <www. un.org/documents/ga/res/44/a44r025.htm>. 
the Child provides further interpretation by stating that any form of discipline that is violent, cruel or degrading is unacceptable. The United Nations Children's Fund (UNICEF), A Familiar Face: Violence in the lives of children and adolescents, ${ }^{30}$ defines violent discipline as, “ “. . any physical punishment and/or psychological aggression".

In their 2017 report, UNICEF has worked with more than 70 countries with the government, schools and partners for awareness, capacity building to prevent forms of violence in school settings. An evaluation indicated that tolerance increased and violent behaviour and conflicts decreased or were mostly resolved without violence in participating schools. In the same report it is stated that data analysis from Ethiopia, India, Peru and Viet Nam indicated that:

"The most commonly reported factors that contributed to feelings of being unsafe at school included exposure to humiliating language, frequent physical fights and harassment from other students... violence in schools, including physical and verbal abuse by teachers and by other students, is the most common reason children expressed for disliking school, and is significantly associated with lower scores in mathematics, self-efficacy and self-esteem."

The definition of Corporal Punishment as defined by The Committee on the Rights of the Children could be seen as follows:

“....as any punishment which physical use of force is used and is intended to cause some degree of pain or discomfort, however light. Most involve hitting (smacking, slapping, spanking) children with the hand or an implement - a whip, stick, belt, shoe, wooden spoon etc. But it can also involve for example, kicking, shaking or throwing children scratching, pinching, biting, pulling hair or boxing ears, forcing children to stay in uncomfortable positions, burning, scalding or forced ingestion ( for example, washing children's mouth out with soap or forcing them to swallow hot spices.). In the view of the Committee, there are other nonphysical forms of punishment that are also so cruel and degrading and thus incompatible with the Convention. These include for example, punishment

${ }^{30}$ United Nations Children's Fund, A Familiar Face: Violence in the lives of children and adolescents, UNICEF, New York, 2017 p 37 
which belittles, denigrates, scapegoats, threatens, scare or ridicules the child"31.

In the research paper, ${ }^{32}$ the impact and association of corporal punishment on children is linked to a wide range of negative outcomes with no positive impact.

It is argued that the findings disclosed that there is an overwhelmingly convincing case that corporal punishment is harmful for children, adults and societies. The assertion is advanced that prohibition is a low-cost effective public health measure on areas of in the prevention of domestic violence, mental illness, antisocial behaviour and to aid welfare, education and developmental outcomes for children. It also seeks to negate or response to the usual arguments defending corporal punishment that starts with the argument that:

"Some individuals have experienced corporal punishment without experiencing the negative effects described in this paper; the harmful outcomes associated with physical punishment may actually be due to other factors; studies showing negative outcomes are about "abuse" rather than "ordinary" physical punishment; research has not distinguished between the effects of physical punishment and other punishments; the effects of physical punishment vary across cultures or according to context; that it has not been shown that all corporal punishment is harmful."

An important document to review is the United Nations (UN) World Report on Violence Children ${ }^{33}$ to dispel the idea that violence does not

\footnotetext{
${ }^{31}$ Committee on the Rights of the Child, General Comment No. 8 (2006): The right of the child to protection from corporal punishment and other cruel or degrading forms of punishment, CRC/C/GC/8, United Nations, Geneva, 2 March 2007, available at <http://srsg.violenceagainstchildren.org/document/crcc-gc-8_369>.

32 Corporal punishment of children: review of research on its impact and associations. Global Initiative to end all Corporal Punishment of Children. http://endcorporalpunishment.org/wp-content/uploads/research/Researcheffects-review-2016-06.pdf, Accessed 26 Oct 2019. See also Ending violent punishment of children - a foundation of a world free from fear and violence. Global Initiative to End All Corporal Punishment of Children, http://endcorporalpunishment.org/resources/thematic-publications/sustainabledevelopment-goals-indicators-briefing-2015/, accessed 26 Oct 2019.
} 
exist or is justified or has insignificant impact. According to the report, violence in school covers both the physical and psychological, and it usually occurs together. Teacher and other school staff may with or without overt or approval by the relevant authority act to inflict physical cum corporal punishment and other cruel and humiliating forms of punishment or treatment and bullying. Children likewise may be perpetuating violence in bullying (include cyber bullying), sexual and gender-based violence, schoolyard fighting, gang violence, and assault with weapons.

Corporal punishment and peer violence has negative impact not only physically but mentally. The negative impact as a result of violence at school may include impact on the health, social and education development of these children. Physical symptoms included headache, stomach ache, backache and dizziness, while psychological symptoms included bad temper, feeling nervous, lonely and helpless. On the social impact it is reported to block social skills, become passive, overly cautious. They are less likely to internalize moral values, resist temptation, engage in altruistic behaviour or exercise moral judgement. Academically there is lack of interest in academia, absenteeism and resorting to other unsavoury activities and dropping out of school.

Likewise, a 2014 study ${ }^{34}$ conducted in Cambodia, Indonesia, Nepal, Pakistan and Vietnam on violence in schools from gender based lens also support negative impact of violence. More than half of students in the schools except Pakistan find schools unsafe.

${ }^{33}$ Pinheiro, Paulo Sérgio, World Report on Violence against Children, United Nations Secretary-General's Study on Violence against Children, Geneva, 2006, available at <www.unicef.org/violencestudy>. https://www.unicef.org/violencestudy/I.\%20World\%20Report\%20on\%20Violen ce\%20against\%20Children.pdf, accessed 26 July 2018.

${ }^{34}$ Bhatla, N., P. Achyut, N. Khan, and S. Walia. "Are schools safe and gender equal spaces? Findings from a baseline study of school related gender-based violence in five countries in Asia." (2014). International Center for Research on Women (ICRW) and Plan International. 


\section{RISK FACTORS CUM VIOLENCE AND IMPACT}

In the United Nations study, ${ }^{35}$ it is reported that physical, emotional based punishments, bullying, verbal abuse and sexual assaults in schools are the main causes of skipping school, dropping out of schools and a low academic achievement.

It was reported that studies in South Asia indicated that violence in school especially corporal punishment have resulted in a significant number of students dropping out of school entirely. It was surmised that risk factors increase the changes of the child being a victim or perpetrator of school-based violence. Individual and external elements (including outside the school environment) are related to either increasing or decreasing the probability of the student being the perpetrator or a victim. It is recognised that violence in schools is more about patterns of violence than isolated cases. That having more friends in school reduces the risk of violent behaviours. The risk factors and the impacts can be mediated by protective factor which rests on a concept of resilience and is documented to be important for violence prevention and a number of other risk behaviours. It is noteworthy to record that whilst family members and friends are critical to making children less vulnerable school violence; research confirms that behaviours of the head of departments, teachers and other employees are also essential ${ }^{36}$.

These adults act as a role model for children, thus, if they demonstrate abusive or violent behaviour such as disrespecting the rights, comfort and safety of others, these young students will follow their actions as well. ${ }^{37}$

\section{MALAYSIAN INTERNATIONAL COMMITMENTS}

\section{United Nations Instruments}

The CRC was acceded by Malaysia on 17 Feb 1995. A child is, "every human-being below the age of eighteen years unless under the law

\footnotetext{
35 footnote 33 .

${ }^{36}$ Pinheiro, P. S. World report on violence against children. (2006) Geneva, Switzerland: ATAR Roto Presse

${ }^{37}$ Greene, M. B. Reducing violence and aggression in schools. Trauma Violence \& Abuse, 6(3), ( 2005) 236-253.
} 
applicable to the child, the majority is attained earlier." Hence, the scope would cover school children in the usual case. It would seem that Malaysia adopts somewhat a conflicted approach with regard to discipline. Malaysia has made reservations for Article 37 but not Article 19 and Article 28 (2) as will be seen later.

"The Government of Malaysia accepts the provisions of the Convention on the Rights of the Child but expresses reservations with respect to articles 2, 7, 14, 28 paragraph 1 (a) and 37, of the Convention and declares that the said provisions shall be applicable only if they are in equal conformity with the Constitution, national laws and national policies of the Government of Malaysia" 38 .

Article 37 which is directly relevant, refers inter alia to the right of the child not to be subjected to torture or cruel or other degrading treatment.

Article 28(2) is not reserved. Article 28(2) provides "State parties shall take all appropriate measures to ensure that schools discipline is administered in a manner consistent with the child's human dignity and is in conformity with the present convention."

Article 19 imposes on the state the obligation to protect the child against "all forms of physical or mental violence, injury or abuse, neglect or negligent treatment, maltreatment or exploitation, including sexual abuse...from any other person who has the care of the child."

This could be argued to include schools and teachers who are in local parentis. ${ }^{39}$ Further there is the General Comment No.8; the Committee on the Rights of the Child further states that any form of discipline that is violent, cruel or degrading is unacceptable ${ }^{40}$.

${ }^{38}$ United Nations Treaty Collection. Convention on the rights of the child. (2010) Accessed July $27 \quad 2018$ https://treaties.un.org/pages/ViewDetails.aspx?src=TREATY\&mtdsg_no=IV$11 \&$ chapter $=4 \&$ lang=en\#EndDec.

${ }^{39}$ Mohammed Ishak Abdul Hammed et al, Duty of care of educational administrators and higher education institutions in Malaysia [2015] 1 MLJ xiv. ${ }^{40} \mathrm{Committee}$ on the Rights of the Child. Report of the committee on the rights of the child. ( 2006) Accessed July 272018 Retrieved from http://www.refworld.org/pdfid/48db55362.pdf. 
This however is not in alignment with Malaysia reservation under Article 37 by which Malaysia reserved her obligation to protect the child from torture or cruel or other degrading treatment.

Does it mean that Malaysia validates or affirms children being subjected to torture or cruel or degrading treatment? A reflection and reconsideration is needed as it violates a basic core of a child right and incompatible with other positive obligations accepted by Malaysia.

It may be argued that notwithstanding the reservation to Article 37, Malaysia is not advocating that a child is to be subjected to torture or cruel or other degrading behaviour. Malaysia has taken action under the Child Act 2001 for child protection wherein the person who abuses a child in his care is subjected to Section 31 . This is also seen in a physical and non-physical emotional context.

(1) Any person who, being a person having the care of a child-

(a)abuses, neglects, abandons or exposes the child or acts negligently in a manner likely to cause him physical or emotional injury or causes or permits him to be so abused, neglected, abandoned or exposed; or

(b) Sexually abuses the child or causes or permits him to be so abused, commits an offence and shall on conviction be liable to a fine not exceeding fifty thousand ringgit or to imprisonment for a term not exceeding twenty years or to both.

While it was emphasized that the process of education must be founded on and foster the rights under CRC such as the right to freedom of expression of art (Art 13) and shield them from any form of sexual abuse or exploitation (Art 34). All respective states must also ensure that children are shielded against bullying and any other form of violence. The Committee notes that any failure to do so may deny the right of education of the child (Art 28 and Art 29).

With regard to bullying, The UN General Assembly resolution adopted emphasized the CRC as the standard to promote and protect rights of the child and the State responsibility to undertake the legislative, administrative and other measure to do so. The Members states are encouraged among others.

(a) to take all appropriate measures to prevent and protect children including in school from any form of violence including forms of bullying, by promptly responding to such acts and to provide 
appropriate support to children affected by and involved in bullying. And (b) to continue to promote and invest in education, including as a long term and lifelong process by which everyone learns tolerance and respect for the dignity of others and the means and methods of ensuring such respect in all societies.

In this regard, there is a push to resolve issues of discipline not from a punitive stance but from a whole school environment-based approach. This is only possible with the development or modification of programs where required with philosophy of restorative justice and positive discipline being its core essence especially in primary school.

\section{RESILIENCE AND OTHER PROTECTIVE FACTORS}

It is a fact that good parenting and a stable home environment are vital in building physical and mental strength. Additionally, even the family members or communities can help children build resilience.Studies in Australia provide evidence of the importance of comprehensive and whole based school methods in decreasing the elements of risk and enhancing the protective elements at the same time ${ }^{41}$.

A whole school system approach with support from teachers, parents, other adults, supportive peers and belonging to a supportive pro-social group are protective factors. Protective factors are present in a school setting such as relationships with other compassionate and mentoring adults by the adults exhibiting pro-social behaviour, providing guidance and offering protection (in which upright teachers performs daily).Respective schools may also encourage development of a resilient team of school mates and enhance their social bond in order to build resilience, empathy, critical thinking and conflict management ${ }^{42}$.

Child resilience can be referred to as the capacity of the child "to cope successfully with everyday challenges including life transitions, times

${ }^{41}$ D. Stewart and J. Sun. "How can we build resilience in primary school aged children? The importance of social support from adults and peers in family, school and community settings," Asia Pacific Journal of Public Health 16, no.1 (2004), 37-41.

${ }^{42}$ U.S. Department of Health and Human Services, Youth violence: A report of the surgeon general. (2001) https://www.ncbi.nlm.nih.gov/books/NBK44294/, accessed July 282018. 
of cumulative stress and significant adversity and risk. Typically, resilient children are recognised by their high self-esteem, internal locus of control, optimism and clear aspirations achievement and goalorientation, reflection and problem-solving capacity, healthy communication patterns and the capacity to seek out mentoring adult relationships"43

\section{CONCLUSION}

It is timely for the Ministry of Education (MOE) to carry out a pilot study on the impact of restorative practices and positive discipline perhaps in conjunction with UNICEF and other expert bodies as conducted by other jurisdictions Ministries Education ${ }^{44}$. This will enable an informed decision as the mode of discipline to be practised in schools to ensure and facilitate the realisation of the MOE vision of the envisaged and full development the ideal Malaysian human being ${ }^{45}$. If we start with the presumption that within the heart of each child there lives a superhero trying to cope and learning to live, not just in the academic context but in the development of a wholesome being, we will be more willing to consider the alternative modes of discipline.

${ }^{43}$ A. Butchart and A.P Harvey, Preventing child maltreatment: A guide to taking action and generating evidence, (North Rhine-Westphalia: World Health Organization Press, 2009).

${ }^{44}$ Matthew Fanselow and Donella Bellet, Evaluation of restorative practices: A positive behaviour for learning programme report prepared for the Ministry of Education New Zealand 31 May 2018 Ministry of Education available at www.educationcounts.govt.nz /publications, Ministry of education Singapore Accessed 24 Oct 2019 http://moe.gov.sg/education/programmes/social-and emotional- learning/discipline 25 Oct 2019. Noted though is the maintenance of laws for physical punishment of -discipline. WestEd Justice \& Prevention Research Center (February 2016) Trevor Francis, Hannah Persson, Sarah Guckenberg, Nancy Hurley and Anthony Petrosino Restorative Justice in U.S. Schools : A Research Review West Ed .org Accessed 31 Oct 2019 http://jprc.wested.org/. and Thomas G Ryan and Sean Ruddy, "Restorative justice: a changing community response", International Electronic Journal of Elementary Education 7, no.2 (2015), 253-262.

45 Malaysian Education Blueprint 2013-2025 ( Preschool to Secondary) (https://www.moe.gov.my/menumedia/media-cetak/penerbitan/dasar/1207malaysia-education-blueprint-2013-2025/file, 2-9, Accessed 26 August 2019. 